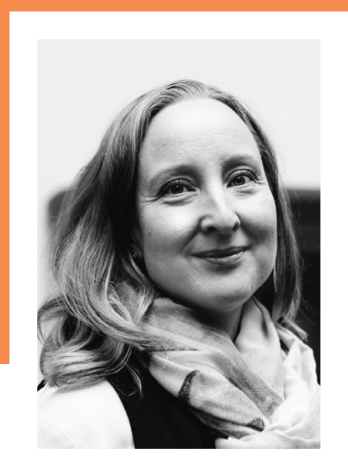

\title{
P̈̈̈̈KIRJOITUS
}

\section{MEIDÄN AIKAMME SIVISTYS}

K

olmena Perättäisenä vuonna Aikuiskasvatus on palkinnut Vuoden tiedeartikkelin tunnustuksella tutkijoita, jotka osallistuvat ajankohtaiseen keskusteluun sivistyksestä. Aikalaisanalyysia sivistyksestä käydään muissakin kotimaisissa tiedelehdissä (esim. Tomperi \& Belt, 2019; Ikonen \& Pehkonen, 2016). Myös esimerkiksi Sitra on herännyt aiheen äärelle ja tukee uusimmalla projektillaan sivistyksen uutta nousua (Lahti \& Mero, 2020).

Minkälaisia merkityksiä tutkijat sivistykselle antavat? Mikä tekee siitä edelleen yhteiskunnallisesti tärkeää?

Tutkijoiden kesken näyttäisi vallitsevan yksimielisyys siitä, että sivistyneisyyttä osoittaa laaja-alainen ja avarakatseinen perehtyneisyys asioihin. Sivistynyt ihminen kykenee oppimansa pohjalta muodostamaan kokonaisvaltaisen ymmärryksen maailman tilasta ja käytännöissään edistämään yhteistä hyvää.

SIVISTYKSESTÄ PUHUESSAMME ilmaisemme arvostuksiamme, ihanteitamme ja niiden taustaideologioita. Yhdyssanojen sivistys-alkuosalla määritämme asioiden toivottua luonnetta: Sivistysvaltiossa tavoitellaan kansalaisten yhdenvertaisia koulutusmahdollisuuksia ja korkeaa koulutustasoa. Sivistysyliopistossa puolustetaan akateemista vapautta, tutkimuksen ja opetuksen yhteyttä sekä kokonaisvaltaiseen harmoniseen persoonallisuuteen kasvattamista.

Sivistyksen aatehistoria sisältää kuitenkin myös ristiriitoja ja valtakamppailuja. Sivistykseen kuuluu olennaisena kulttuurisen pääoman hallinta, jolla tuotetaan ryhmien välisiä eroja ja rajoja (Ikonen \& Pehkonen, 2016).

Sivistys on jännitteisessä suhteessa sosiaalisen taustan eroihin, kuten koulutuksen historian ja tasa-arvon tutkija Annukka Jauhiainen Aikuiskasvatuksen tutkimuspäivien pääluennossaan muistutti. Hän nosti esiin, kuinka eronteon ajatus sisältyy jo sivistys-termin etymologiaan. Vanhoissa murteissa 'sivistäminen' ilmaisi pellavan puhtaaksi harjaamista, roskien ja sileän kuiden erottamista toisistaan. Kansansivistystyö 1800-luvulla määritteli korkeasti koulutetun eliitin suhdetta kansaan, jota tuolloin edustivat maaseutujen talonpojat ja kaupunkien työväestö.

SUOMALAINEN SIVISTYNEISTÖ ei vapaan kansansivistystyön alkutaipaleellakaan, 1900-luvun alkupuolella, muodostanut ideologisesti yhtenäistä joukkoa, vaan sivistyksen merkityksestä on ollut eriäviä näkemyksiä. Silti kansansivistystyön pioneerit halusivat nostaa sivistyksen ideaalin näiden kiistojen yläpuolelle. 


\title{
KESKUSTELUSSA SIVISTYKSESTÄ ON OTETTAVA HUOMIOON
}

\author{
KATEGORISOINNIT, JOILLA IHMISIÄ ASETETAAN \\ ERIARVOISEEN SUHTEESEEN KESKENÄ̈̈N.
}

"Yksi piirre yrityksissä luoda vapaalle kansansivistystyölle omaleimaista teoriaperustaa oli pyrkimys ylittää aatteelliset erot. Samalla kun korostettiin suvaitsevaisuutta ja erilaisen aatesisällön hyväksyntää, vedottiin sellaisiin universaaleihin 'vapauden' ja ihmisyyden arvoihin, jotka ylittävät ideologiat ja yhteiskunnallisten ryhmien erityiset pyrkimykset." (Miettinen 2017, 85).

Hyvistä aikeista huolimatta kulttuurisesti vallalla olevat sivistyneen ihmisen ideaalit, kuten oppineisuus, järkevyys, itsenäisyys, avoimuus ja eettisyys, eivät välity kaikille saman sisältöisinä. Siksi keskustelussa sivistyksestä on otettava huomioon kategorisoinnit, joilla ihmisiä asetetaan eriarvoiseen suhteeseen keskenään. Ketkä nykyisessä keskustelussa asettuvat sivistyksen kohteiksi, ketkä saavat luoda uutta sivistystä ja keiden vastuulla on viedä sivistyksen perinnettä eteenpäin?

KESKUSTELU SIVISTYKSESTÄ on väistämättä sidoksissa ihmiskuntaa maailmanlaajuisesti koskettaviin viheliäisiin ongelmiin (wicked problems), kuten ilmastonmuutokseen, luonnonvarojen ja luonnon monimuotoisuuden katoamiseen, epidemioiden leviämiseen, sosiaaliseen epäoikeudenmukaisuuteen ja köyhyyteen. Ongelmien monimutkaisuus, epämääräisyys ja yhteensopimattomuus edellyttävät uusia lähestymistapoja.

Tarvitaan monitieteisyyttä ja tieteidenvälisyyttä, eli asioiden tarkastelemista osana laajoja systeemisiä kokonaisuuksia. Tarvitaan avoimuutta ja yhteiskunnallista vuorovaikutusta. Tarvitaan "kovien" ja "pehmeiden" tieteenalojen, perus- ja soveltavan tutkimuksen, sekä yleis- ja ammattisivistyksen välisten vastakkainasettelujen purkamista.

Sivistysyliopistoihanteen elvyttäminen ja sivistystavoitteiden päivittäminen kaikilla koulutuksen alueilla ovat avaimia siihen, että pystymme yhdessä tarttumaan viheliäisiin ongelmiin. Sivistyksellä on väliä myös tutkijoiden ja opettajien työssään kokeman tyytyväisyyden ja motivaation kannalta. Oma työ tuntuu merkitykselliseltä silloin, kun voi kokea olevansa osa suurempaa sivistystehtävää.

Sivistys on vastuunkantoa tulevaisuudesta.

Ulpukka Isopahkala-Bouret

\section{Lisää aiheesta:}

Heikkinen, H. L.T \& Kukkonen, H. (2019).

Ammattikorkeakoulu toisin ajateltuna. Osaaminen, sivistys ja tiedon intressit. Aikuiskasvatus (39)4, 262-275.

Ikonen, M. \& Pehkonen, L. (2016). Tieteellinen sivistys: kamppailua näkyvyydestä, maineesta ja paremmuudesta? Kasvatus \& Aika (10)4, 62-78.

Lahti, V. M. \& Mero, P. (2020). Sivistyksen tarina elää ajassa. Blogiteksti. Sitra. https://www.sitra.fi/blogit/ sivistyksen-tarina-elaa-ajassa.

Miettinen, R. (2017). Aikuiskasvatus, sivistys ja työn tulevaisuus. Aikuiskasvatus (37)2, 84-95.

Salonen, A. O. \& Joutsenvirta, M. (2018). Vauraus ja sivistys yltäkylläisyyden ajan jälkeen. Aikuiskasvatus (38)2, 84-101.

Tomperi, T. \& Belt, J. (2019). Johdatukseksi sivistyksen ajattelemiseen. niin\&näin 1/2019. 